\title{
SEASONAL INDUCTION OF CLUSTER ROOTS IN Embothrium coccineum J.R. Forst. \& G. Forst. IN THE FIELD: FACTORS THAT REGULATE THEIR DEVELOPMENT
}

\author{
Gabriel Donoso-Nanculao $^{1 *}$, Mauricio Castro ${ }^{1}$, Darío Navarrete ${ }^{1}$, León A. Bravo ${ }^{1}$, and Luis J. Corcuera ${ }^{1}$
}

\begin{abstract}
Embothrium coccineum J.R. Forst. \& G. Forst. (Proteaceae) is a tree that grows successfully in nutrient poor soils of southern Chile at full sunlight. Under these conditions it develops cluster roots (CR). However, the induction of CR on this species has not been studied completely. The aim of this work was to study the effect of seasonality, soil and weeds in the development of CR in E. coccineum. The present study was performed in Los Lagos Region ( $41^{\circ} 72^{\prime}$ S lat), Chile. Plants of E. coccineum were grown in sandy soils in presence or absence of weeds, using two concentrations of organic matter. The number of CR per plant, CR mass and P concentration in leaves was measured during the four seasons in E. coccineum plants. The CR development in the soil with high organic matter concentration and without weeds was observed in autumn, spring and summer, and in the soil with low organic matter concentration was observed in autumn, winter and spring. Not found related of this result with the foliar $\mathrm{P}$ concentration in E. coccineum. The results suggest a strong seasonal and weeds effect on CR development in $E$. coccineum under field conditions.
\end{abstract}

Key words: Embothrium coccineum, cluster roots, phosphorus deficiency, root development.

\section{INTRODUCTION}

Embothrium coccineum J.R. Forst. \& G. Forst. is a member of Proteaceae family. This species grows between 35 to $56^{\circ} \mathrm{S}$ lat (Rodríguez et al., 1983) and from sea level to $1300 \mathrm{~m}$ altitude (Alberdi and Donoso, 2004). It is considered a shade intolerant pioneer tree (Alberdi and Donoso, 2004). It grows successfully in nutrient impoverished soil in south of Chile like other members of Proteaceae (Skene, 1998). These environmental conditions could favor the development of cluster roots (CR) in E. coccineum (Donoso, 2006). Cluster roots were defined as those portions of lateral roots with dense cluster of rootlets (at least 10) per centimeter (Purnell, 1960). This type of roots increases the absorption surface area and modifies the chemistry of the rhyzosphere through release of large amounts of organic acids, phenolic compounds, enzymes, mucilage, and water. This

${ }^{1}$ Universidad de Concepción, Facultad de Ciencias Naturales y Oceanográficas, Casilla 160-C, Concepción, Chile. "Corresponding author (gabdonos@udec.cl).

Part of this study was presented at XI Chilean Congress of Soil Science, 24-26 Agosto 2009. Sociedad Chilena de la Ciencia del Suelo, Chillán, Chile.

Received: 2 June 2010.

Accepted: 22 September 2010. characteristic allows the solubilization and absorption of unavailable phosphates chelated with $\mathrm{Al}, \mathrm{Ca}$, and $\mathrm{Fe}$ by CR (Lambers and Poot, 2003; Shane et al., 2003).

In Lupinus albus L., the CR induction depends principally on $\mathrm{P}, \mathrm{N}, \mathrm{Fe}, \mathrm{Mg}$ or $\mathrm{Zn}$ deficiency (Shane et al., 2003; Shen et al., 2003). However, few studies have related the effect of other factors on $\mathrm{CR}$ induction as seasonality, presence of weeds, and soil type (Lamont and Bergl, 1991). Seasonal changes associated to climatic data and especially plant developmental stage could have a relevant role in CR induction (Lamont, 2003). Indeed, Australian Proteaceaes as Banksia menziesii R. Br., B. attenuata R. Br., and B. hookeriana Meisn. develop $\mathrm{CR}$ only in humidity seasons (winter-spring) (Lamont and Bergl, 1991). In addition, was observed that water application in summer can induce the CR formation and water availability between 1 and 2 times the field capacity of soil is optimal for CR development and decrease it with the waterlogging (Lamont, 1976).

Furthermore, soil type could play an important role. For example, the decrease $\mathrm{P}$ availability by presence of high Al concentration in soil induces CR formation (Shu et al., 2007). Additionally, CR are preferentially developed in the upper soil layers, where nutrients especially organic matter are enriched (Lamont, 1973). 
The presence of weeds is not considered a factor in $\mathrm{CR}$ induction. However, weeds could have a fundamental role in allelopathic effect of root exudates of weeds with phytotoxic effects in trees root (Bais et al., 2006). In addition, they compete for water and nutrients, affecting $\mathrm{N}$ and $\mathrm{P}$ uptake from soil and inducing a decrease in root and shoot development (Donoso et al., 2007).

E. coccineum grows in contrasting soil conditions where develops cluster roots. For this reason, this species appears as a good model to test the hypothesis that the development of $\mathrm{CR}$ in E. coccineum is dependent of season, soil type and presence of weed. The objective of this work was to study the effect of seasonality, soil type and weeds presence in the development of CR of $E$. coccineum.

\section{MATERIALS AND METHODS}

\section{Study site characterization}

Minimal and maximal temperatures and seasonal rainfall between years 2004 and 2008 was determined using a Licor data logger (LI-COR, LI-1400, Lincoln, Nebraska) with air temperature and rainfall sensors (LI-COR, LI 1400-106, Lincoln, Nebraska, USA). The study was made

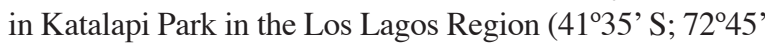
W), Chile, where E. coccineum growth naturally. Mean annual temperature is $9{ }^{\circ} \mathrm{C}$ and annual precipitation is near $1700 \mathrm{~mm}$. The soil in the study site is a sandy loam texture with low $\mathrm{P}$ and high $\mathrm{Al}$ concentration (Table 1). High presence of weeds was observed principally members of Poaceae (2.5 x $10^{4}$ plants $\left.\mathrm{m}^{-2}\right)$ and occasionally Hypochaeris radicata L. $\left(1.8 \times 10^{3}\right.$ plants $\left.\mathrm{m}^{-2}\right)$. Weeds develop a superficial intricate root system in the first layer of soil (4 cm deep) composed mainly of fine roots. Two types of soil from natural habitat of E. coccineum in south of Chile were used. Representative soil samples were obtained from $20 \mathrm{~cm}$ depth in soil under weed presence with high organic matter $(\mathrm{W})$ and soils without weeds with high organic matter (HOM) and soils with low organic matter (LOM). Physic and chemistry characterization of each soil consisted in measuring the texture, content of organic matter, $\mathrm{pH}$, nitrate, $\mathrm{P}, \mathrm{K}, \mathrm{Fe}$ and $\mathrm{Al}$ contents. These analyses were performed in Soil Laboratory of Universidad de Concepción in Chillán, Chile (Sadzawka et al., 2004).

\section{Plant material}

Forty juvenile plants of E. coccineum from $1 \mathrm{yr}$ old were harvested during the four seasons, in April (autumn), July (winter), November (spring) in 2007 and January (summer) in 2008. Immediately after harvesting, leaves were frozen in liquid $\mathrm{N}\left(\mathrm{N}_{2(1)}\right)$ for $\mathrm{P}$ determination and root were weighed and height of stem was measured. Additionally, the number of healthy (non senescent) CR was determined for each plant. Eighty juvenile plants of E. coccineum from $1 \mathrm{yr}$ old were transplanted to weedfree soil (HOM and LOM) between August to November in 2007. Weed-free soil was obtained after removing the surface $4 \mathrm{~cm}$ layer of weed roots. Forty of these plants were planted into a HOM soil parcel of $8 \mathrm{~m}^{2}$. The other 40 plants were planted into LOM soil parcel of $8 \mathrm{~m}^{2}$ (Table 1). Eight to ten plants of each parcel were harvested completely randomized in April (autumn), July (winter), November (spring) in 2008 and January (summer) in 2009. Leaf of this plants was freezing in $\mathrm{N}_{2(1)}$ for $\mathrm{P}$ determination. After all, adhering soil was removed and root was weighed and the number of healthy CR was counted per plant. The growth of plants was evaluated to measure the competition effect in E. coccineum by weeds presence. For this one, stem height of plants grown in

Table 1. Physical and chemical characteristics of soil.

\begin{tabular}{lccc}
\hline & \multicolumn{3}{c}{ Values } \\
\cline { 2 - 4 } Properties & W & HOM & LOM \\
\hline Texture & Sandy loam & Sandy loam & Sandy loam \\
Sand, $\%$ & 61 & 71 & 52 \\
Clay, $\%$ & 4.3 & 6.1 & 3.3 \\
Loam, \% & 35 & 23 & 45 \\
Organic matter, $\%$ & 27 & 22 & 5.0 \\
pH & 5.5 & 4.4 & 5.6 \\
Nitrate $\left(\mathrm{N}^{-N_{3}}\right), \mathrm{mg} \mathrm{kg}^{-1}$ & 1.9 & 75 & 21 \\
P(Olsen), $\mathrm{mg} \mathrm{kg}^{-1}$ & 0.1 & 2.6 & 0.5 \\
Available K, mg kg-1 & 83 & 62 & 43 \\
Available Fe, mg kg-1 & 43 & 11 & 17 \\
Al saturation, $\%$ & 44 & 34 & 63 \\
\hline
\end{tabular}

W: high organic matter soil with weeds presence; HOM: high organic matter soil; LOM: low organic matter soil. 
both HOM and W soils in spring of 2008 and summer of 2009 (growth season E. coccineum, Romero et al., 1987), was measured ever in the same individuals $(n=8-10)$.

\section{Phosphate inorganic determination in leaf}

Inorganic phosphate $(\mathrm{Pi})$ determinations were made in leaves of plants in the four seasons. Leaves were frozen and ground in $\mathrm{N}_{2(1)}$. Inorganic phosphate was extracted from leaves with $2 \%(\mathrm{v} / \mathrm{v})$ acetic acid and quantified as described by Murphy and Riley (1962).

\section{Statistical analysis}

Data were analyzed with two-way ANOVA. The two analyzed factors were season and soil type. Differences between treatments were tested using Tukey $(\alpha=0.05)$. To ensure normality and homogeneity of variances, data were log-transformed where necessary. All analyses were performed using SigmaStat 3.1 (Systat Software, Richmond, California, USA).

\section{RESULTS AND DISCUSSION}

\section{Microclimatic characterization}

Precipitation was highest in winter $(650 \mathrm{~mm})$. July of 2007 and May, July and August of 2008 were the rainiest months (245 and $413 \mathrm{~mm}, 305$ and $267 \mathrm{~mm}$, respectively) (Figure 1). Rainfall was low in spring and summer, but there was not a precipitation-free month. Mean minimum air temperature ranged between 0 and $9{ }^{\circ} \mathrm{C}$ in August and January, respectively. Mean maximum air temperature ranged between 8 and $19{ }^{\circ} \mathrm{C}$ in July and January, respectively.

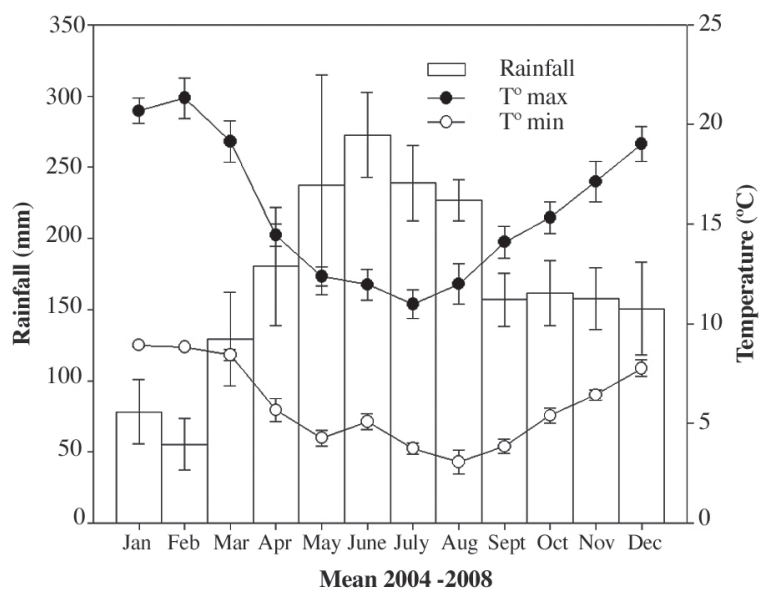

$T_{\text {max }}^{\circ}$ : mean monthly maximum temperature; $T_{\text {min }}^{\circ}$ : mean monthly minimum temperature.

Error bars represent standard error.

Figure 1. Annual course of rainfall and temperature in Pichiquillaipe (South Central of Chile).

\section{Soil characterization}

All soils were classified into the texture namely sandy loam (Table 1). The $\mathrm{W}$ soil had an organic matter percentage similar to HOM soil and both have four to five times more organic matter than LOM soil. The $\mathrm{pH}$ in the three analyzed soils was acid (4.4-5.6). HOM soil had the highest nitrate concentration $\left(75 \mathrm{mg} \mathrm{kg}^{-1}\right)$ followed by LOM soil which had a nitrate concentration of $21 \mathrm{mg} \mathrm{kg}^{-1}$. The $\mathrm{W}$ soil was the poorest in nitrate with only $0.1 \mathrm{mg} \mathrm{kg}^{-1}$. The $\mathrm{P}$ values of soils were no greater than $2.6 \mathrm{mg} \mathrm{kg}^{-1}$. According to this $\mathrm{P}$ contents these soils were classified as very low (Jones, 1999). The $\mathrm{W}$ soil has the highest $\mathrm{K}$ and Fe concentration with 83 and $43 \mathrm{mg} \mathrm{kg}^{-1}$, respectively. $\mathrm{HOM}$ soil had the second $\mathrm{K}$ concentration $(62 \mathrm{mg}$ $\mathrm{kg}^{-1}$ ) and LOM soil had the lowest K concentration (43 $\mathrm{mg} \mathrm{kg}^{-1}$ ). Iron concentration was similar between HOM soil and LOM soil with 11 and $17 \mathrm{mg} \mathrm{kg}^{-1}$, respectively. Finally, Al concentration was high in all soils with value of $\mathrm{Al}$ saturation no less than $34 \%$.

\section{Seasonal induction of $\mathbf{C R}$}

The number of CR between seasons in plants grown in both HOM and LOM soils showed differences between seasons (Figure 2A and 2B) $(P \leq 0.001)$. However, soil type had not effect in $\mathrm{CR}$ number $(P=0.178)$. Marked seasonality in the occurrence of CR in E. coccineum was consistent with previous findings in other Proteaceae such as Banksia prionotes (Jeschke and Pate, 1995), Hakea species (Lamont, 1973) and Leucadendron laureolum (Lam.) Fourc. (Lamont et al., 1984).

In HOM soil the highest number of clusters was observed in summer (20 CR per plant). The second number of $\mathrm{CR}$ was observed in autumn and spring, which were seven to eight times higher than that observed in winter. At these seasons maximum rainfall was $150 \mathrm{~mm}$ and maximum average temperatures was $21{ }^{\circ} \mathrm{C}$, respectively. This finding was similar to that observed by other authors in Australian Proteaceae, where the CR emergence occurred in seasons where rainfall corresponding $120 \mathrm{~mm}$ and temperature maximum was $22{ }^{\circ} \mathrm{C}$ (Lamont, 1976). However, the disappearance of the $\mathrm{CR}$ in very rainy and cold winter months had not been documented yet.

On the other hand, the number of CR of plants grown in LOM soil in winter, autumn and spring was three to five times higher than in summer with 5 to $9 \mathrm{CR}$ per plant. Although, in autumn and spring there was no difference in the number of CR. E. coccineum grown in LOM soil showed a large decreased in both proportion of CR per total root mass and number of CR per plant in summer and slight decreased in winter. In winter, the number of CR in plant grown in LOM soil was 10 times higher than number of $\mathrm{CR}$ in plants grown in HOM soil. In summer 

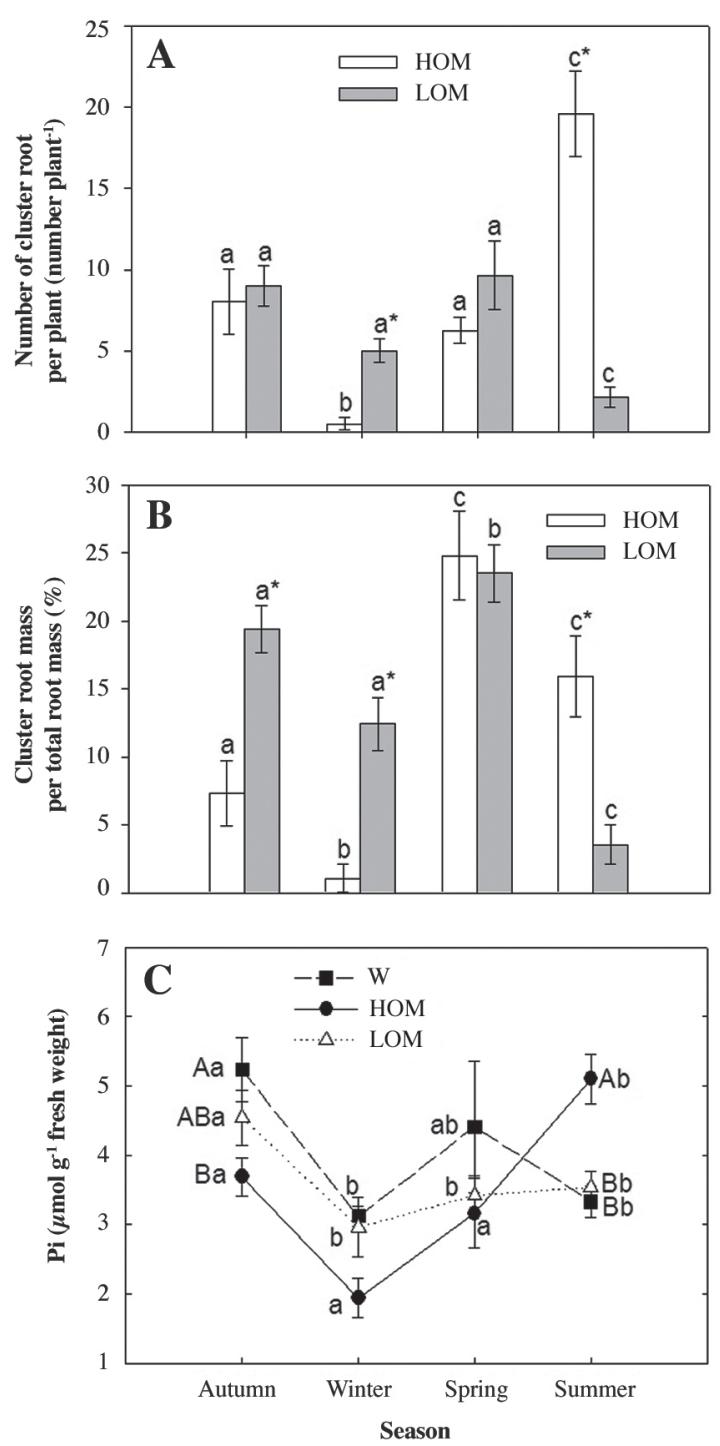

HOM: high organic matter soil. LOM: low organic matter soil. W: high organic matter soil with weeds presence.

Error bar represent the standard error of means $(n=8-10)$. Letter indicates the difference between seasons into each soil condition and the asterisk $(*)$ indicates the difference between soil into the season (A and B).

Error bar represent standard error of mean $(n=4-5)$. Lowercase letters indicate the difference between seasons into each soil condition and uppercase letters indicate the difference between soil type into the season $(\mathrm{C})$.

For all two way ANOVA and Tukey test method a Pairwise Multiple Comparison Procedure was used $(\mathrm{P} \leq 0.05)$.

Figure 2. Number of cluster roots per plant in Embothrium coccineum grown in HOM and LOM soils through four seasons (A), percent of CR fresh mass per root fresh mass $(B)$ and inorganic phosphate (Pi) concentration in leaves in a seasonal course $(C)$. the number of CR in plant grown in HOM was 10 times higher than plants grown in LOM soil. The difference in seasonal CR formation in both soils could be due to a difference in the amount of organic matter. Some reports indicate that the presence of organic matter in sandy soils increases the moisture-holding capacity, which is an important factor on the emergence of CR (Ehlers and Goss, 2003; Rawls et al., 2003). However, it is unknown whether there are differences in moisture holding capacity of soil and whether these differences directly influence the appearance of roots. We think that the organic matter favors the retention of moisture in summer but in winter it may cause low drainage in a flooding condition. Furthermore, low organic matter in LOM soil could keep ideal soil moisture to $\mathrm{CR}$ formation in the rainy season but would be unable to keep moisture in dry summer, unsuitable conditions for the formation of CR (Lamont, 1976).

Seasonal and soil effect was observed for percentage of $\mathrm{CR}$ mass by total root mass $(\mathrm{P} \leq 0.001$ and $\mathrm{P} \leq$ 0.001 , respectively) (Figure $2 \mathrm{~B}$ ). The highest value of percentage of CR mass per total root mass system was observed in spring (25\%). In summer and autumn the CR mass were 7-14 times higher than that observed in winter, respectively. Also, plants grown in LOM soil also showed differences in the number of CR mass between seasons. In winter, and in autumn and spring, the number of CR mass was 4 to 7 times higher than summer with $12 \%$ to $24 \%$ CR mass per total root mass. In addition, we observed an increase in CR mass from winter to spring. In autumn and winter, the CR mass of plant grown in LOM soil was higher than plants grown in HOM soil in 2 to 11 times, respectively. In summer the value in plant grown in HOM soil was 4.5 times higher than plants grown in LOM soil. Seasonality of CR mass was similar to values of $\mathrm{CR}$ number in both soils. High CR mass in spring in both LOM and HOM soils suggest relation between $E$. coccineum growth season with cluster root development. This finding could be related with phytohormone induction of CR because auxin, a principal inductor of CR studied (Gilbert et al., 2000; Skene and James, 2000; Casimiro et al., 2001; Ljung et al., 2001; López-Bucio et al., 2005), is synthesized and transported in a period of growth of the plants (Schrader et al., 2003; Yörük et al., 2005; Nagar and Sood, 2006). Nevertheless, further studies are needed to reveal possible changes in auxin levels and transport during the growing season and its effect in the induction of $\mathrm{CR}$ in E. coccineum.

\section{Seasonal phosphate inorganic determination in leaves}

To determine the relationship between plant $\mathrm{P}$ status and $\mathrm{CR}$ induction, we measured the inorganic phosphate (Pi) concentration in leaves of plants grown in different 
soils condition in a seasonal course (Figure 2C). Seasonal effect in Pi concentration in leaves was shown $(P \leq 0.001)$ and soil type effect was not observed $(P=$ $0.178)$. In plant grown in $\mathrm{W}$ soil the Pi concentration in leaves was 1.6 times greater in autumn than in winter and summer and non statistical differences were found between autumn and spring. Seasonal Pi concentration in leaves of plants grown in LOM soil was similar to plants grown in $\mathrm{W}$ soil. In addition, Pi concentration of plants grown in HOM soil was the highest in summer with a value of $1.3,1.6$ and 2.6 times greater than autumn, spring and winter, respectively. When the $\mathrm{Pi}$ concentration was compared between different soil conditions, only in autumn and summer were observed differences. In autumn, Pi concentration of plants grown in $\mathrm{W}$ soil was 1.4 times higher than plants grown in HOM soils. Although in summer, plant grown in HOM was 1.4 times higher Pi concentration than plants grown in LOM and $\mathrm{W}$ soils.

The relationship between the number of proteoid roots and foliar P concentrations in soil plants LOM

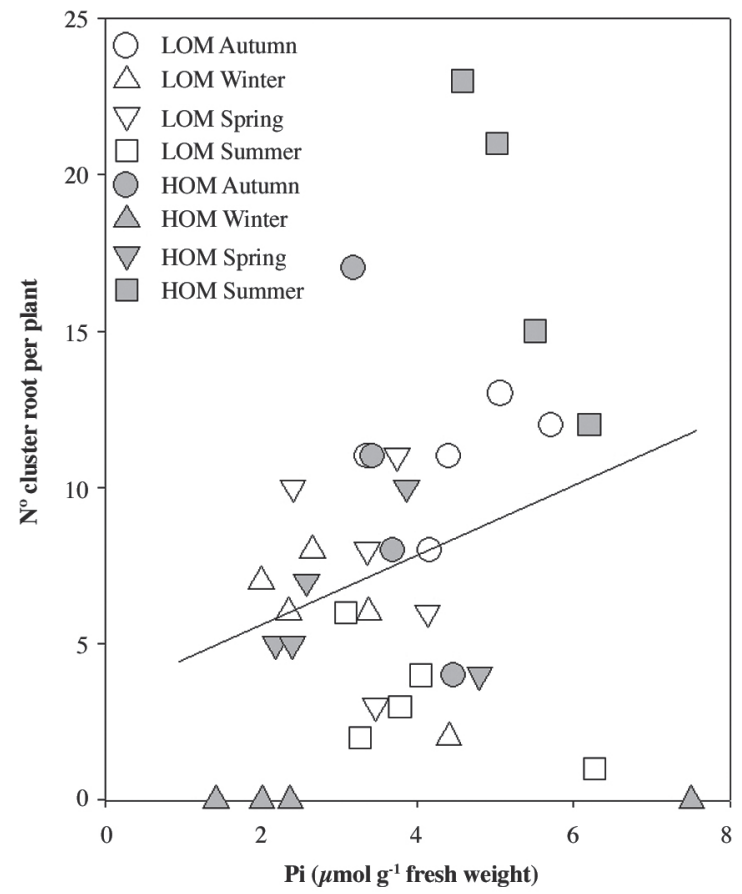

HOM: high organic matter soil; LOM: low organic matter soil; W: high organic matter soil with weeds presence.

Open symbol represents plants grown in LOM soil and gray symbol represents plants grown in HOM soil. Each point represents one plant $\left(\mathrm{y}=0.06 \mathrm{x}+3.4 ; \mathrm{r}^{2}=0.06 ; P=0.179\right)$.

Figure 3. Relationship between inorganic phosphate (Pi) concentration in leaves and cluster root number of Embothrium coccineum in different conditions. and HOM was analyzed (Figure 3). We observed that in most of plants had between 2 to $10 \mathrm{CR}$ in a range of foliar P from 2 to $6 \mu \mathrm{mol} \mathrm{g}^{-1}$ fresh mass. The maximum number of CR was observed in a plant grown in HOM soil in summer with a foliar $\mathrm{P}$ concentration of 4 $\mu \mathrm{mol} \mathrm{g}^{-1}$ fresh mass and the minimum value of CR was observed in plants grown in W soil with a leaf $\mathrm{P}$ concentration from 1.5 to $7.5 \mu \mathrm{mol} \mathrm{\textrm {g } ^ { - 1 }}$. However, low $R$-square value $\left(\mathrm{r}^{2}=0.06 ; \mathrm{P}=0.179\right)$ suggests that other factors also influenced $\mathrm{CR}$ induction. It is known that low $\mathrm{P}$ soil in E. coccineum growth in greenhouse (Zúñiga-Feest et al., 2010) and low levels of foliar P in other Proteaceas members (Shane et al., 2003; Shen et al., 2003; Shane and Lambers, 2005) induce the formation of CR. Contrary to the expected, lowest levels in leaf $\mathrm{P}$ in E. coccineum grown in HOM, LOM and W soils had no relation with CR formation. However, it was noted that $\mathrm{P}$ levels in leaf in E. coccineum grown in HOM and LOM soils were increased along with the number and mass of CR. This finding would indicate that the $\mathrm{CR}$ would enhance the acquisition of $\mathrm{P}$ in E. coccineum.

\section{Effect of weeds in stem growth of $\boldsymbol{E}$. coccineum}

In all season no differences were observed in the number of CR between seasons in plant grown in W soil with mean of CR of $0.4 \pm 0.2$ (standard error) by plant. This is the first time that the presence of weed is reported to cause almost complete disappearance of $\mathrm{CR}$ in $E$. coccineum. It is more probably that the direct contact between the lateral roots of E. coccineum with the roots of these weeds, growing in upper $4 \mathrm{~cm}$ of soil, could interfere with their development. This would affect the CR formation because it develops from lateral roots in $E$. coccineum as other Proteaceae (Jeschke and Pate, 1995). To evaluation of possible role of weeds in growing of $E$. coccineum, we measured the height of stem in growing season (spring to summer) (Figure 4). For experimental design was contrasted height of plants grown in $\mathrm{W}$ and HOM soils because they had similar backgrounds. The growth between spring to summer of plants in HOM soil was 2 times more higher than plant grown in $\mathrm{W}$ soil. The decrease of growth was not due to leaf $\mathrm{P}$ status because plants had similar leaf of $\mathrm{P}$ levels as plants growth in LOM soil. The soil analysis possibly gives us an explanation because in $\mathrm{W}$ soil low $\mathrm{N}$ was observed in comparison with without weed. This could be the answer for the low growth of plants observed in these soils. The same effect has been observed in similar soils in southern Chile by Donoso et al. (2007). It remains to determine whether the low growth of E. coccineum in W soil is due to water, nutrient or space competition or allelopathy by weeds growing around the E. coccineum as described in 


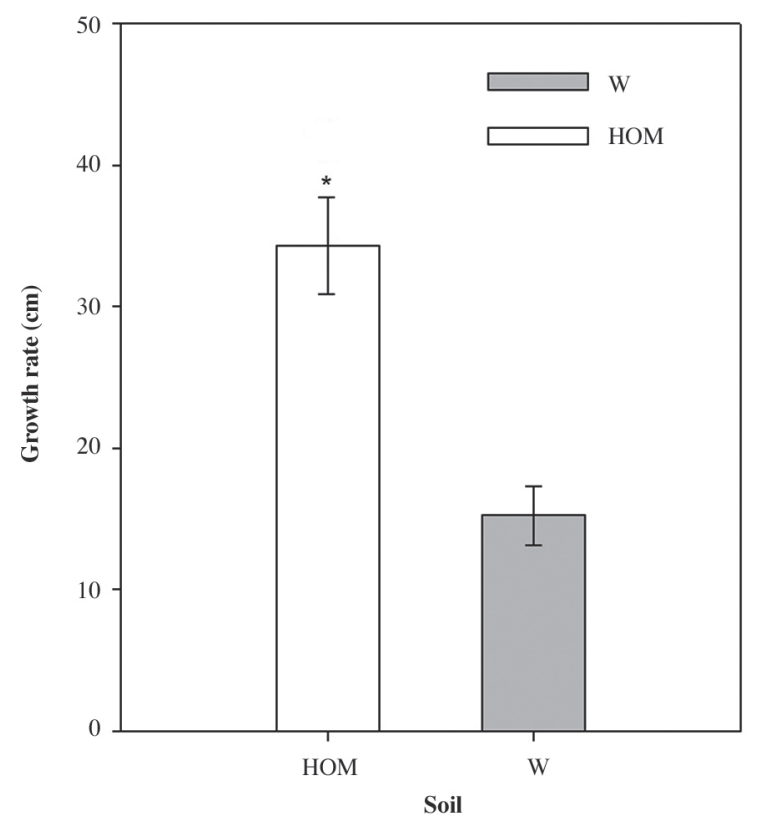

HOM: high organic matter soil; W: high organic matter soil with weeds presence.

*Difference using $t$-test $(P \leq 0.05)$.

The measured of the stem height of Embothrium coccineum was made in October and January.

Figure 4. Stem growth of Embothrium coccineum in growth season in presence of weeds.

many reports about plant-plant interactions (SánchezMoreiras et al., 2003; Bais et al., 2006).

\section{CONCLUSIONS}

Cluster roots induction is strongly regulated by climatic seasonal changes, depending on the organic matter soil content and weed presence on field plants of E. coccineum. On the other side, weed coverage induce almost completely of CR formation. Finally, low $\mathrm{Pi}$ concentration in leaves does not induce of $\mathrm{CR}$ under field conditions. The study presented here represents the first field description of seasonal CR formation in E. coccineum an endemic species of Chile and Argentina.

\section{ACKNOWLEDGEMENTS}

The author thanks MECESUP Chile UCO0214 for doctoral fellowship, as well as FONDECYT grant $\mathrm{N}^{\mathrm{o}} 1050640$ for financial support, and Dra. Miren Alberdi and Dr. Enrique Peñaloza for helpful information about cluster root.

\section{RESUMEN}

Inducción estacional de raíces proteoideas en Embothrium coccineum J.R. Forst. \& G. Forst. en el campo: Factores que regulan su desarrollo. Embothrium coccineum J.R. Forst. \& G. Forst. (Proteaceae) es un árbol que crece en suelos pobres en nutrientes del sur de Chile a pleno sol. En estas condiciones desarrolla raíces proteoideas. Sin embargo, la inducción de raíces proteoideas en esta especie no ha sido estudiada completamente. El objetivo de este trabajo fue estudiar el efecto de la estacionalidad, suelo y malezas en el desarrollo de las raíces proteoideas en E. coccineum. El presente estudio fue desarrollado en la Región de Los Lagos (4172' lat. S), Chile. Las plantas se cultivaron en suelo arenoso en presencia o ausencia de malezas, utilizando dos concentraciones de materia orgánica. El número de raíces proteoideas por planta, el peso de las raíces proteoideas y la concentración de $\mathrm{P}$ foliar, se midieron durante las cuatro estaciones en plantas de $E$. coccineum. El desarrollo de las raíces proteoideas en el suelo con alta concentración de materia orgánica y sin malezas fue observado en otoño, primavera y verano y en el suelo con baja concentración de materia orgánica fue observado en otoño, invierno y primavera. No se encontró relación de este resultado con la concentración de P foliar en E. coccineum. Los resultados sugieren un fuerte efecto estacional y de las malezas en el desarrollo de las raíces proteoideas en E. coccineum en condiciones de campo.

Palabras clave: Embothrium coccineum, raíces proteoideas, deficiencia de fósforo, desarrollo radical.

\section{LITERATURE CITED}

Alberdi, M., y C. Donoso. 2004. Variabilidad en Embothrium coccineum. p. 345-356. In Donoso, C., A. Premoli, L. Gallo, and R. Ipinza (eds.) Variación intraespecífica en las especies arbóreas de los bosques templados de Chile y Argentina. Editorial Universitaria, Santiago, Chile.

Bais, H.P., T.L. Weir, L.G. Perry, S. Gilroy, and J.M. Vivanco. 2006. The role of root exudates in rhizosphere interactions with plants and other organisms. Annual Review of Plant Biology 57:233-266.

Casimiro, I., A. Marchant, R.P. Bhalerao, T. Beeckman, S. Dhooge, R. Swarup, et al. 2001. Auxin transport promotes Arabidopsis lateral root initiation. Plant Cell 13:843-852.

Donoso, C. 2006. Las especies arbóreas de los bosques templados de Chile y Argentina, Autoecología. p. 235-236. María Cúneo, Valdivia, Chile. 
Donoso, P.J., V. Gerding, D. Uteau, D.P. Soto, O. Thiers, and C. Donoso. 2007. Effects of fertilization doses and weed cover on the initial growth and mortality of a Nothofagus dombeyi plantation in the Valdivian Andes. Bosque 28:249-255.

Ehlers, W., and M.J. Goss. 2003. Water dynamics in plant production. p. 15-16. CABI Publishing, Bristol, UK.

Gilbert, G.A., J.D. Knight, C.P. Vance, and D.L. Allan. 2000. Proteoid root development of phosphorus deficient lupin is mimicked by auxin and phosphonate. Annals of Botany 85:921-928.

Jeschke, W.D., and J.S. Pate. 1995. Mineral nutrition and transport in xylem and phloem of Banksia prionotes (Proteaceae), a tree with dimorphic root morphology. Journal of Experimental Botany 46:895-905.

Jones, J.B. 1999. Soil analysis handbook of reference methods. p. 88. CRC Press, Boca Raton, Florida, USA.

Lambers, J.T., and P. Poot. 2003. Structure and functioning of cluster roots and plant responses to phosphate deficiency. Series: Developments in Plant and Soil Sciences. Vol. 97. 376 p. Reprinted from Plant and Soil.

Lamont, B.B. 1973. Factors affecting the distribution of proteoid roots within the root systems of two Hakea species. Australian Journal of Botany 24:691-702.

Lamont, B. 1976. The effects of seasonality and waterlogging on the root systems of a number of Hakea species. Australian Journal of Botany 24:691-702.

Lamont, B.B. 2003. Structure, ecology and physiology of root clusters- a review. Plant and Soil 248:1-19.

Lamont, B., G. Brown, and D.L. Mitchell. 1984. Structure, environmental effects on their formation, and function of proteoid roots in Leucadendron laureolum (Proteaceae). New Phytologist 97:381-390.

Lamont, B.B., and S.M. Bergl. 1991. Water relations, shoot and root architecture, and phenology of three co-occurring Banksia species: No evidence for niche differentiation in the pattern of water use. Oikos 60:291-298.

Ljung, K., R.P. Bhalerao, and G. Sandberg. 2001. Sites and homeostatic control of auxin biosynthesis in Arabidopsis during vegetative growth. Plant Journal 28:465-474.

López-Bucio, J., E. Hernández-Abreu, L. SánchezCalderón, A. Pérez-Torres, R.A. Rampey, B. Bartel, and L. Herrera-Estrella. 2005. An auxin transport independent pathway is involved in phosphate stressinduced root architectural alterations in Arabidopsis. Identification of BIG as a mediator of auxin in pericycle cell activation. Plant Physiology 137:681-691.
Murphy, J., and J.P. Riley. 1962. A modified single solution method for the determination of phosphate in natural waters. Analytica Chimica Acta 27:3136.

Nagar, P., and S. Sood. 2006. Changes in endogenous auxins during winter dormancy in tea (Camellia sinensis L.) O. Kuntze. Acta Physiologiae Plantarum 28:165-169.

Purnell, H.M. 1960. Studies of the family Proteaceae. I. Anatomy and morphology of the roots of some Victorian species. Australian Journal of Botany 11:267-285.

Rawls, W.J., Y.A. Pachepsky, J.C. Ritchie, T.M. Sobecki, and H. Bloodworth. 2003. Effect of soil organic carbon on soil water retention. Geoderma 116:61-76.

Rodríguez, R., O. Mathei, y M. Quezada. 1983. Flora arbórea de Chile. Editorial de la Universidad de Concepción, Concepción, Chile.

Romero, M., M. Riveros, C. Cox, and M. Alberdi. 1987. Growth dynamics and phenologie of Embothrium coccineum Forst. at different altitudes. Revista Brasileña de Botánica 10:139-145.

Sadzawka, A., M.A. Carrasco, R. Grez, y M.L. Mora. 2004. Métodos de análisis recomendados para los suelos Chilenos. 113 p. Comisión de Normalización y Acreditación, Sociedad Chilena de la Ciencia del Suelo, Santiago, Chile.

Sánchez-Moreiras, A., O. Weiss, and M. Reigosa-Roger. 2003. Allelopathic evidence in the Poaceae. Botanical Review 69:300-319.

Schrader, J., K. Baba, S.T. May, K. Palme, M. Bennett, R.P. Bhalerao, and G. Sandberg. 2003. Polar auxin transport in the wood-forming tissues of hybrid aspen is under simultaneous control of developmental and environmental signals. Proceedings of the National Academy of Sciences of the United States of America 100:10096-10101.

Shane, M.W., M. de Vos, S. de Roock, G.R. Cawthray, and H. Lambers. 2003. Effects of external phosphorus supply on internal phosphorus concentration and the initiation, growth and exudation of cluster roots in Hakea prostrata R.Br. Plant and Soil 248:209-219.

Shane, M.W., and H. Lambers. 2005. Cluster roots: A curiosity in context. Plant and Soil 274:99-123.

Shen, J., Z. Rengel, C. Tang, and F. Zhang. 2003. Role of phosphorus nutrition in development of cluster roots and release of carboxylates in soil-grown Lupinus albus. Plant and Soil 248:199-206. 
Shu, L., J. Shen, Z. Rengel, C. Tang, F. Zhang, and G.R. Cawthray. 2007. Formation of cluster roots and citrate exudation by Lupinus albus in response to localized application of different phosphorus sources. Plant Science 172:1017-1024.

Skene, K.R. 1998. Cluster roots: some ecological considerations. Journal of Ecology 86:1062-1066.

Skene, K.R., and W.M. James. 2000. A comparison of the effects of auxin on cluster root initiation and development in Grevillea robusta Cunn. ex R. Br. (Proteaceae) and in the genus Lupinus (Leguminosae). Plant and Soil 219:221-229.
Yörük, I., M. Türker, P. Battal, A. Kazankaya, and B.Tileklioğlu. 2005. Seasonal changes of endogenous plant hormones in Rosa canina. Acta Horticulturae 690:199-202.

Zúñiga-Feest, A., M. Delgado, and M. Alberdi. 2010. The effect of phosphorus on growth and cluster-root formation in the Chilean Proteaceae: Embothrium coccineum (R. et J. Forst.). Plant and Soil. doi:10.1007/ s11104-010-0419-x. 